Jurnal Tanah dan Sumberdaya Lahan Vol 8 No 1: 249-258, 2021

e-ISSN:2549-9793, doi: 10.21776/ub.jts1.2021.008.1.28

\title{
PENGARUH KUALITAS KOMPOS PAITAN (Tithonia diversifolia) DAN KOTORAN SAPI TERHADAP HASIL DAN BINTIL AKAR TANAMAN KEDELAI (Glycine max. L.) PADA ALFISOL Effect of Quality of Paitan (Tithonia diversifolia) Compost and Cow Dung on Soybean (Glycine max. L.) Yield and Root Nodules on Alfisol
}

\author{
Lelalovita Siregar ${ }^{*}$, Yulia Nuraini ${ }^{1}$ \\ Jurusan Tanah, Fakultas Pertanian, Universitas Brawijaya, Jl. Veteran No. 1, Malang 65145 \\ *Penulis korespondensi: lelalovitas@gmail.com
}

\begin{abstract}
Indonesia has around $82 \%$ of the total 58 million ha of agricultural land, which is classified as suboptimal due to intensive land management and not concerned with soil fertility. Therefore, it is necessary to add organic material which is expected to increase soil fertility. Compost is an organic soil repairer that can reduce the use of chemical fertilizers so that it can increase yield and plant root nodules are largely determined by the quality parameters contained therein. This study was aimed to explore the effect of quality of paitan (Tithonia diversifolia) compost and cow dung on soybean (Glycine max. L.) yield and root nodules. This study was conducted using a randomized block design with two stages, i.e., compost making with five treatments and three replications and compost application with six treatments and three replications. The results showed that the quality of the compost was able to increase the yield and nodules of soybean $\mathrm{n}$ plants. There was a positive correlation between compost quality and soybean yield.
\end{abstract}

Keywords: compost quality, organic fertilizer, soybean production

\section{Pendahuluan}

Lahan sub optimal di Indonesia disebabkan oleh penurunan kesuburan tanah karena pengelolaan lahan yang intensif dan tidak mementingkan keberlanjutan tanah, salah satunya adalah penggunaan pupuk kimia secara terus-menerus tanpa diimbnagi dengan penambahan bahan organik. Menurut Suriadikarta dan Simanungkalit (2006), bahan organik dapat berasal dari kompos, pupuk hijau, pupuk kandang, sisa panen, limbah ternak, limbah industri maupun limbah kota. Alfisol berpotensi untuk budidaya tanaman palawija, salah satu diantaranya adalah tanaman kedelai.

Tanaman kedelai merupakan tanaman pangan yang penting bagi masyarakat Indonesia sebagai sumber protein dan kandungan gizi yang banyak yang berpotensi untuk pertumbuhan dan kesehatan. Berdasarkan Wahyuningsih (2019), kebutuhan kedelai di
Indonesia pada tahun 2019 sebesar 2,49 juta ton sedangkan ketersediaanya hanya sebesar 1,46 juta ton. Rendahnya produktivitas ini karena budidaya kedelai dilakukan pada lahan yang sub optimal sementara kedelai membutuhkan unsur hara yang tinggi. Menurut Sumarno dan Mashuri (2016), kedelai membutuhkan bahan organik sedang sampai tinggi, unsur hara $\mathrm{N}$ tinggi $(0,21-0,75 \%)$, unsur hara $\mathrm{P}$ tinggi ( $11-15$ $\mathrm{ppm})$, unsur hara $\mathrm{K}$ tinggi $\left(0,6-12 \mathrm{me} 100 \mathrm{~g}^{-1}\right)$ dan $\mathrm{pH}$ tanah sekitar 6,0 - 6,5 Maka dari itu, perlunya teknologi pertanian yang bertujuan meningkatkan kesuburan tanah melalui penambahan bahan organik.

Kompos merupakan bahan organik yang sudah melewati proses dekomposisi oleh mikroorganisme pengurai hingga esensial bagi tanaman (Setyorini et al., 2006). Kompos yang berasal dari bahan organik Paitan (Tithonia diversifolia) dan kotoran sapi yang diaplikasikan 
Jurnal Tanah dan Sumberdaya Lahan Vol 8 No 1: 249-258, 2021

e-ISSN:2549-9793, doi: 10.21776/ub.jts1.2021.008.1.28

mampu meningkatkan kesuburan tanah sehingga berpotensi dalam meningkatkan produktivitas tanaman kedelai. Penelitian Martajaya et al. (2010), bahwa pemberian pupuk organik berupa Tithonia diversifolia dan kotoran sapi pada tanaman jagung manis memperoleh hasil sebesar $\left(11,4 \mathrm{t} \mathrm{ha}^{-1}\right.$ dan 11,2 $\left.\mathrm{t} \mathrm{ha}^{-1}\right)$. Dalam memperbaiki pertumbuhan dan produksi tanaman kemampuan kompos sangat ditentukan kualitas kompos tersebut, yang disesuaikan dengan persyaratan teknis minimal pupuk organik padat Kepmentan No.261/KPTS/SR.310/M/4/2019.

Kompos yang berasal dari Paitan dan atau kotoran sapi perlu diteliti lebih lanjut berdasarkan proporsi bahan organik dengan tujuan menghasilkan kompos yang berkualitas yang diharapkan dapat memperbaiki kesuburan tanah dan meningkatkan produksi tanaman kedelai.

Berdasarkan banyaknya manfaat dengan penambahan kompos yaitu Paitan dan kotoran sapi maka penelitian ini bertujuan untuk mengetahui dan menganalisis 1) kualitas kompos Paitan dan atau kotoran, 2) pengaruh kualitas kompos terhadap hasil tanaman kedelai berupa berat brangkasan, jumlah polong, berat polong dan berat 100 biji, serta jumlah bintil dan jumlah bintil akar efektif, 3) hubungan antara kualitas kompos terhadap hasil dan bintil akar tanaman kedelai.

\section{Bahan dan Metode}

\section{Tempat dan waktu penelitian}

Penelitian ini dilaksanakan pada bulan Februari - Juli 2020. Terdiri atas dua tahapan penelitian. Tahap pertama yaitu pembuatan kompos yang berlokasi di UPT Kompos Universitas Brawijaya, Malang dan analisis kompos yang dilaksanakan di Laboratorium Kimia Tanah FPUB. Tahap kedua yaitu aplikasi kompos yang dilaksanakan di Greenhouse Jatimulyo Malang dengan pengambilan sampel tanah yang berasal dari Agrotechno Park Jatikerto Universitas Brawijaya.

\section{Rancangan percobaan}

Penelitian tahap satu menggunakan Rancangan Acak Kelompok (RAK), dengan 5 perlakuan dan 3 ulangan (Tabel 1) sehingga didapatkan 15 satuan percobaan. Penelitian tahap dua menggunakan Rancangan Acak Kelompok (RAK), 6 perlakuan dan 3 ulangan (Tabel 2) sehingga didapatkan 18 satuan percobaan.

Tabel 1. Perlakuan pembuatan kompos paitan dan kotoran sapi.

\begin{tabular}{ccc}
\hline No & Kode & Perlakuan \\
\hline 1 & P1 & $15 \mathrm{~kg} \mathrm{P}$ \\
2 & P2 & $15 \mathrm{~kg} \mathrm{KS}$ \\
3 & P3 & $11,25 \mathrm{~kg} \mathrm{P}+3,75 \mathrm{~kg} \mathrm{KS}$ \\
4 & P4 & $7,5 \mathrm{~kg} \mathrm{P}+7,5 \mathrm{~kg} \mathrm{KS}$ \\
5 & P5 & $3,75 \mathrm{~kg} \mathrm{P}+11,25 \mathrm{KS}$ \\
\hline
\end{tabular}

Keterangan: P : Paitan, KS: Kotoran Sapi.

Tabel 2. Aplikasi kompos paitan dan kotoran sapi terhadap tanaman kedelai.

\begin{tabular}{ccc}
\hline No & Kode & Perlakuan \\
\hline 1 & P0 & Kontrol (Tanpa kompos) \\
2 & P1 & $100 \% \mathrm{P}$ \\
3 & P2 & $100 \% \mathrm{KS}$ \\
4 & P3 & $75 \% \mathrm{P}+25 \% \mathrm{KS}$ \\
5 & P4 & $50 \% \mathrm{P}+50 \% \mathrm{KS}$ \\
6 & P5 & $25 \% \mathrm{P}+75 \% \mathrm{KS}$ \\
\hline
\end{tabular}

Keterangan: P : Paitan, KS: Kotoran Sapi.

\section{Pelaksanaan penelitian}

Tahap satu (pembutan kompos paitan dan kotoran sapi)

Bahan utama yang digunakan adalah $400 \mathrm{~kg}$ Paitan segar (dalam kondisi muda maupun tua) berasal lahan Jatimulyo dan $200 \mathrm{~kg}$ kotoran sapi segar yang berasal dari peternakan Sumber Sekar sebagai bahan pembuatan kompos. Metode yang digunakan saat pembuatan kompos adalah Berkeley untuk kombinasi kompos paitan dan kotoran sapi, sedangkan pada bahan kompos tanpa kombinasi menggunakan metode Heap (Setyorini et al., 2006). Pembuatan kompos dimulai dari penyediaan daun Paitan dan kotoran sapi sebagai bahan baku kompos. Menghaluskan daun Paitan menggunakan mesin grinder hingga berukuran 1,25-2 cm. Pembuatan kompos dalam kotak dengan proporsi bahan yang berbeda-beda yaitu: $15 \mathrm{~kg}$ Paitan; $15 \mathrm{~kg}$ kotoran sapi; 11,25 kg Paitan $+3,75 \mathrm{~kg}$ kotoran sapi, 7,5 kg Paitan + 7,5 kg kotoran sapi, 3,75 kg Paitan 


\section{Jurnal Tanah dan Sumberdaya Lahan Vol 8 No 1: 249-258, 2021}

e-ISSN:2549-9793, doi: 10.21776/ub.jts1.2021.008.1.28

+ 11,25 kg kotoran sapi. Bahan kompos yang sudah disiapkan diaduk dan ditambahkan air secukupnya, apabila sudah homogen dimasukan kedalam kotak kayu yang sudah diberi label untuk membedakan perbedaan proporsi bahan organik kemudian ditutup dengan penutup kayu.

\section{Tahap dua (aplikasi kompos paitan dan kotoran sapi)}

Pengambilan sampel tanah dilakukan di Agrotechno Park Universitas Brawijaya yang terletak di Desa Jatikerto, Malang yang berjenis tanah Alfisol (Nuraini, 2012). Sampel tanah diambil pada kedalaman 0-20 $\mathrm{cm}$ kemudian dikering anginkan. Selanjutnya tanah ditumbuk dan diayak menggunakan ayakan berdiameter 2 $\mathrm{mm}$, dimasukkan kedalam polybag dan ditimbang sebanyak $5 \mathrm{~kg}$. Aplikasi kompos dilakukan sebelum penanaman kedelai dengan mencampur kompos dengan tanah. Sebelum penanaman, benih kedelai DEGA 1 direndam 15 menit dengan air kemudian dicampur inokulan Rhizobium merek Agrisoy produksinya Balitkabi, kemudian ditanam dua biji setiap polybag dan diaplikasikan pupuk SP36 dengan dosis $100 \mathrm{~kg} \mathrm{ha} \mathrm{k}^{-1}$. Pada saat 7 hari setelah tanam dilakukan pemupukan Urea $\left(75 \mathrm{~kg} \mathrm{ha}^{-1}\right)$ dan $\mathrm{KCl}\left(100 \mathrm{~kg} \mathrm{ha}^{-1}\right)$. Pemeliharaan tanaman kedelai dilakukan setiap hari. Kegiatan yang dilakukan selama pemeliharaan adalah penyiraman, penjarangan, penyiangan dan pemupukan. Penyiraman dilakukan setiap hari yaitu pada pagi hari dengan kebutuhan 1,4 L polybag untuk penyiraman selanjutnya disesuaikan berat polybag. Penyiangan dilakukan secara manual apabila sudah terdapat gulma. Pemupukan menggunakan pupuk dasar SP36 $100 \mathrm{~kg} \mathrm{ha}^{-1}$ saat tanam dan pupuk Urea $75 \mathrm{~kg} \mathrm{ha}^{-1}$ serta $\mathrm{KCl}$ $100 \mathrm{~kg} \mathrm{ha}^{-1}$ pada saat 7 hari setelah tanam. Pengendalian hama yang dilakukan dengan cara mekanis dan pada saat 21-28 HST menggunakan pestisida Curacorn dengan dosis 0,5 $\mathrm{mL} \mathrm{L}^{-1}$ yang diaplikasikan dua kali seminggu setiap pagi hari.

\section{Analisis data}

Data hasil pengamatan pada penelitian tahap 1 dianalisis menggunakan aplikasi Genstat 20.1 dengan uji F (ANOVA) taraf 5\% apabila berpengaruh nyata akan diuji lanjut dengan uji Duncan taraf $5 \%$. Hasil penelitian tahap 2 dianalisis menggunakan aplikasi Genstat 20.1 dengan uji F (ANOVA) taraf 5\% apabila berpengaruh nyata maka akan diuji lanjut menggunakan uji Duncan taraf 5\% serta diuji korelasi taraf 5\% antara parameter kualitas kompos terhadap hasil dan bintil akar tanaman kedelai.

\section{Hasil dan Pembahasan}

\section{Pembuatan kompos paitan dan kotoran sapi}

\section{Bahan baku kompos}

Kompos dibuat dari Paitan dan kotoran sapi yang memiliki kualitas yang berbeda. Menurut (Nuraini, 2012) pencampuran bahan organik menunjukkan hasil yang lebih baik karena dapat menahan pelepasan hara sehingga lebih sinkron dengan kebutuhan tanaman. Berdasarkan hasil analisis kimia bahan baku kompos (Tabel 3), Paitan memiliki nilai rasio $\mathrm{C} / \mathrm{N}$ sebesar 15,71 dan kotoran sapi sebesar 24,15. Pengomposan dilakukan untuk memperoleh nisbah $\mathrm{C} / \mathrm{N}$ yang lebih rendah karena berfungsi mendekomposisi bahan organik agar unsur hara terikat yang terkandung didalamnya menjadi bentuk terlarut dan tersedia bagi tanaman, Rasio C/N diharapkan menurun.

Tabel 3. Analisis dasar kimia bahan organik yang digunakan.

\begin{tabular}{lcc}
\hline Analisis & Paitan & Kotoran Sapi \\
\hline $\mathrm{pH}$ & 8,28 & 8,21 \\
C-organik $(\%)$ & 24,59 & 35,22 \\
$\mathrm{~N}$ total $(\%)$ & 1,56 & 1,46 \\
Rasio C/N & 15,71 & 24,15 \\
K total $(\%)$ & 2,26 & 2,15 \\
\hline
\end{tabular}

\section{Subu kompos}

Pengamatan suhu kompos saat proses pengomposan dilakukan dengan mengukur suhu tiga hari sekali. Berikut merupakan data pengukuran suhu kompos selama pengomposan yang disajikan pada Gambar 1 . Setiap perlakuan mengalami peningkatan suhu dari awal hingga menurun kembali di akhir pengomposan. Hal ini sesuai dengan pernyataan Idham (2017), selama pengomposan tumpukan kompos akan menyebabkan perubahan suhu secara bertahap dari normal mengalami 
Jurnal Tanah dan Sumberdaya Lahan Vol 8 No 1: 249-258, 2021

e-ISSN:2549-9793, doi: 10.21776/ub.jts1.2021.008.1.28

peningkatan mencapai suhu maksimum kemudian akan turun terus-menerus menuju stabil pada saat kompos terurai.

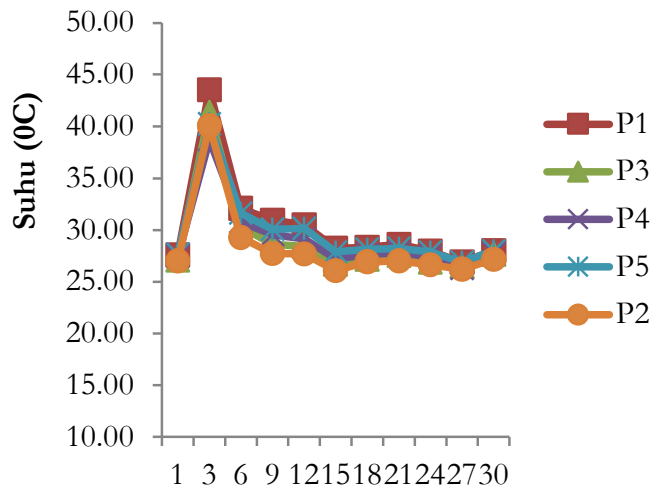

Waktu (HSP : Hari Setelah Pengomposan)

Gambar 1. Perubahan suhu selama pengomposan. P1 : 100\% Paitan, P2 : 100\% Kotoran Sapi, P3 : 75\% Paitan+25\% Kotoran Sapi, P4 : 50\% Paitan+50\% Kotoran Sapi, P5 : $25 \%$ Paitan $+75 \%$ Kotoran Sapi.

\section{Penyusutan berat}

Persentase seluruh perlakuan mengalami penyusutan diatas 25\% (Tabel 4). Penurunan ini disebabkan aktivitas mikroorganisme dalam pengomposan yang telah merombak senyawa organik menjadi senyawa anorganik. Hal ini sesuai dengan pernyataan Syukur dan Nur
(2006), proses pengomposan akan terurai sehingga volume tumpukan akan menyusut kurang lebih tiga perempat hal ini karena perombakan menghasilkan panas yang menguapkan air dan $\mathrm{CO}_{2}$

Tabel 4. Penyusutan kompos.

\begin{tabular}{lc}
\hline Perlakuan & $\begin{array}{c}\text { Penyusutan } \\
\text { Berat (\%) }\end{array}$ \\
\hline P1 (100\% Paitan) & 34,44 \\
P2 (100\% Kotoran Sapi) & 25,11 \\
P3 (75\% Paitan $+25 \%$ & 34,89 \\
Kotoran Sapi) & \\
P4 (50\% Paitan $+50 \%$ & 32,67 \\
Kotoran Sapi) & \\
P5 (25\% Paitan $+75 \%$ & 26,67 \\
Kotoran Sapi) & \\
\hline
\end{tabular}

\section{Kualitas kompos paitan dan kotoran sapi}

Penggunaan Paitan dan kotoran sapi menunjukkan bahwa proses pengomposan yang berlangsung 30 hari telah menghasilkan kompos yang sesuai dengan persyaratan teknis minimal mutu pupuk organik padat sesuai Kepmentan No.261/KPTS/SR.310/M/4/2019 (Tabel 5). Perlakuan perlakuan 100\% Paitan dan 100\% kotoran sapi belum sesuai karena dari N-Total dan K-Total yang masih dibawah 2. Kurangnya unsur hara $\mathrm{N}$ dan $\mathrm{K}$ bukan berarti tidak baik digunakan pada tanaman karena pada $\mathrm{pH}, \mathrm{C}$ organik dan rasio $\mathrm{C} / \mathrm{N}$ telah sesuai, sehingga siap diaplikasikan.

Tabel 5. Hasil analisis kualitas kompos paitan dan kotoran sapi.

\begin{tabular}{|c|c|c|c|c|c|c|}
\hline Parameter & $\begin{array}{c}\text { P1 } \\
(100 \% \mathrm{P})\end{array}$ & $\begin{array}{c}\text { P2 } \\
(100 \% \\
\text { KS })\end{array}$ & $\begin{array}{c}\text { P3 } \\
(75 \% \mathrm{P}+ \\
25 \% \mathrm{KS})\end{array}$ & $\begin{array}{c}\mathrm{P} 4 \\
(50 \% \mathrm{P}+ \\
50 \% \mathrm{KS})\end{array}$ & $\begin{array}{c}\text { P5 } \\
(25 \% \mathrm{P}+ \\
75 \% \mathrm{KS})\end{array}$ & $\begin{array}{c}\text { Persyaratan, } \\
\text { Kepmentan } \\
\text { No.261/KTPS/ } \\
\text { SR.310/M/4/2019 }\end{array}$ \\
\hline $\mathrm{pH}$ & 8,02 & 7,49 & 7,79 & 7,94 & 7,87 & $4-9$ \\
\hline C-organik (\%) & 15,31 & 29,16 & 27,31 & 28,28 & 26,64 & $\min 15$ \\
\hline $\mathrm{N}$ total $(\%)$ & 1,92 & 1,85 & 2,08 & 2,16 & 2,46 & $\min 2$ \\
\hline Rasio C/N & 8,10 & 17,55 & 13,28 & 13,08 & 10,84 & $\leq 25$ \\
\hline $\mathrm{K}$ total $(\%)$ & 3,65 & 1,86 & 2,62 & 2,72 & 2,91 & $\min 2$ \\
\hline
\end{tabular}

\section{Aplikasi kompos}

Berat brangkeasan

Berat brangkasan (basah) merupakan salah satu indikator hasil dari tanaman kedelai.
Berdasarkan Tabel 6, pemberian kompos berpengaruh nyata terhadap berat brangkasan tanaman kedelai. Berat brangkasan tertinggi pada perlakuan P2 (100\% kotoran sapi) dengan berat 99,33 g/tan. Hal ini disebabkan karena P2 
(100\% kotoran sapi) memiliki nilai $\mathrm{pH}$ netral sehingga optimal dalam meningkatkan $\mathrm{pH}$ tanah. Menurut Agustin dan Suntari (2018), dekomposisi lanjut dari pupuk kadang sapi pada kurun waktu penanaman yang sudah melepaskan ion-ion $\mathrm{OH}^{-}$dari kompleks jerapannya sehingga berakibat pada peningkatan $\mathrm{pH}$ tanah. Meningkatnya $\mathrm{pH}$ tanah mendukung tersedianya unsur hara lainnya seperti $\mathrm{N}$ serta menjadi $\mathrm{pH}$ yang sesuai dengan hidupnya bakteri penambat N. Menurut Sumarno et al. (2017), unsur hara nitrogen diserap oleh tanaman kedelai untuk membentuk asam amino, meningkatkan protein dan klorofil dan memperbesar sel agar pertumbuhan tanaman cepat dan berat brangkasan tanaman akan bertambah. Menurut pendapat Meitasari dan Karuniawan (2017), berat brangkasan merupakan indikator penentu besarnya serapan nitrogen yang berhubungan erat dengan pembentukan bintil akar yang akan menambat nitrogen.

Pemberian kompos menghasilkan tanaman yang lebih tinggi dibandingkan kontrol karena terdapat peningkatan suplai fotosintat, hal dimana fotosintat yang rendah akan berpengaruh terhadap bobot total tanaman. Dengan meningkatnya bahan organik tanah berguna memperbaiki sifat fisik tanah maka akar tanaman akan lebih mampu menyerap unsur hara dengan baik sehingga membantu proses metabolisme tanaman dalam perkembangannya hingga berpengaruh pada total berat brangkasannya.

Tabel 6. Berat brangkasan kedelai pada berbagai kombinasi kompos.

\begin{tabular}{lc}
\hline Perlakuan & $\begin{array}{c}\text { Berat Brangkasan } \\
\left(\mathbf{g ~ t a n}^{-1}\right)\end{array}$ \\
\hline P0 (Kontrol) & $42,67 \mathrm{a}$ \\
P1 (100\% Paitan) & $32,33 \mathrm{a}$ \\
P2 (100\% Kotoran & $99,33 \mathrm{c}$ \\
Sapi) & \\
P3 (75\% Paitan + & $66,83 \mathrm{~b}$ \\
25\% Kotoran Sapi & \\
P4 (50\% Paitan + & $69,00 \mathrm{~b}$ \\
50\% Kotoran Sapi & \\
P5 (25\% Paitan + & $64,00 \mathrm{~b}$ \\
75\% Kotoran Sapi & \\
\hline
\end{tabular}

Keterangan: Angka yang diikuti huruf sama pada kolom yang sama menunjukkan tidak berbeda nyata menurut uji Duncan taraf 5\%.
Jumlab polong

Pemberian kompos Paitan dan kotoran sapi tidak berpengaruh nyata terhadap jumlah polong tanaman kedelai (Tabel 7). Namun telah meningkatkan jumlah polong dibandingkan perlakuan kontrol. Jumlah polong tertinggi terdapat pada perlakuan kompos P2 (100\% kotoran sapi) yaitu 40,67 buah/tan. Perlakuan kompos $100 \%$ kotoran sapi yang memiliki Corganik tinggi dan sesuai dengan Kepementan bermanfaat sebagai sumber makanan bakteribakteri tanah dengan berkembangnya bakateri di tanah yang membantu proses metabolism tanaman baik pada fase vegetatif maupun generatif misalnya pembenukan polong sehingga mampu meningkatkan jumlah polong. Menurut Canqui et al. (2013) C-organik dapat memperbaiki sifat-sifat tanah yang dapat meningkatkan produktivitas tanah dan meningkatkan produksi tanaman. Menurut Ridwan et al. (2015), apabila unsur hara yang diserap meningkat maka jumlah polong akan meningkat, dengan pemberian kompos abu boiler $5 \mathrm{t} / \mathrm{ha}$ mampu meningkatkan jumlah polong dibandingkan tanpa pemberian kompos.

Tabel 7. Jumlah polong kedelai pada berbagai kombinasi kompos.

\begin{tabular}{|c|c|}
\hline Perlakuan & $\begin{array}{l}\text { Jumlah Polong } \\
\left.\text { (buah } \tan ^{-1}\right)\end{array}$ \\
\hline P0 (Kontrol) & $28 \mathrm{a}$ \\
\hline P1 (100\% Paitan) & $32 \mathrm{a}$ \\
\hline $\begin{array}{l}\text { P2(100\% Kotoran } \\
\text { sapi }\end{array}$ & $41 \mathrm{a}$ \\
\hline $\begin{array}{l}\text { P3(75\% Paitan }+ \\
25 \% \text { Kotoran Sapi) }\end{array}$ & 36 a \\
\hline $\begin{array}{l}\text { P4 (50\% Paitan }+ \\
50 \% \text { Kotoran Sapi) }\end{array}$ & $35 a$ \\
\hline $\begin{array}{l}\text { P5 }(25 \% \text { Paitan }+ \\
75 \% \text { Kotoran Sapi) }\end{array}$ & $30 \mathrm{a}$ \\
\hline \multicolumn{2}{|c|}{$\begin{array}{l}\text { Keterangan: Angka yang diikuti huruf sama pada } \\
\text { kolom yang sama menunjukkan tidak berbeda nyata } \\
\text { menurut uji Duncan taraf } 5 \% \text {. }\end{array}$} \\
\hline \multicolumn{2}{|l|}{ Berat polong } \\
\hline \multicolumn{2}{|c|}{$\begin{array}{l}\text { Aplikasi kompos berpengaruh nyata terhadap } \\
\text { berat polong kedelai. Kotoran sapi } 100 \% \\
\text { memiliki berat polong tertinggi (Tabel } 8) \text {. Hal } \\
\text { ini karena pH pada kotoran sapi netral dan C- } \\
\text { organik yang tinggi sehingga mampu } \\
\text { meyediakan kebutuhan hara lainnya. Menurut }\end{array}$} \\
\hline
\end{tabular}

http://jtsl.ub.ac.id

253 


\section{Jurnal Tanah dan Sumberdaya Lahan Vol 8 No 1: 249-258, 2021 e-ISSN:2549-9793, doi: 10.21776/ub.jts1.2021.008.1.28}

Utomo et al. (2015), kotoran sapi memiliki kelebihan sebagai sumber hara nitrogen, fosfor dan kalium yang merupakan unsur penting bagi pertumbuhan dan perkembangan tanaman. Unsur hara yang cukup tersebut berpengaruh positif terhadap peningkatan berat polong.

Tabel 8. Berat polong kedelai pada berbagai kombinasi kompos.

\begin{tabular}{|c|c|}
\hline Perlakuan & $\begin{array}{l}\text { Berat Polong } \\
\left(\mathrm{g} \mathrm{tan}^{-1}\right)\end{array}$ \\
\hline P0 (Kontrol) & $38,00 \mathrm{a}$ \\
\hline P1 (100\% Paitan) & $51,00 \mathrm{a}$ \\
\hline P2 (100\%Kotoran Sapi) & $66,00 \mathrm{~b}$ \\
\hline $\begin{array}{l}\text { P3 (75\% Paitan }+25 \% \\
\text { Kotoran Sapi) }\end{array}$ & $46,67 \mathrm{a}$ \\
\hline $\begin{array}{l}\text { P4 (50\% Paitan }+50 \% \\
\text { Kotoran Sapi) }\end{array}$ & $51,67 \mathrm{a}$ \\
\hline $\begin{array}{l}\text { P5 (25\% Paitan }+75 \% \\
\text { Kotoran Sapi) }\end{array}$ & $48,33 \mathrm{a}$ \\
\hline
\end{tabular}

Berat 100 biji

Aplikasi kompos mampu meningkatkan berat 100 biji kedelai (Tabel 9). Berat 100 biji merupakan berat yang menentukan hasil tanaman kedelai sudah optimal. Kompos mampu meningkatkan 46,37\% dari berat kontrol berat 100 biji $(44,16 \mathrm{~g} / 100$ biji) pada perlakuan $100 \%$ kotoran sapi yang merupakan hasil berat 100 biji tertinggi pada tanaman kedelai. Hal ini sesuai dengan penelitian Bertham (2002), bahwa penambahan organik dalam bentuk kompos sebesar $15 \mathrm{t} / \mathrm{ha}$ meningkatkan biji kedelai sekitar 26 sampai $70 \%$. Meningkatnya jumlah 100 biji juga diakibatkan karena diikuti dengan naiknya jumlah bintil akar yang dihasilkan bakteri Rhirobium yang dapat membantu perkembangan tanaman kedelai. Mayani dan Hapsoh (2011) menunjukkan bahwa Rhizobium pada tanaman kedelai dapat meningkatkan bobot biji kering per plot dan bobot 100 biji.

\section{Jumlah bintil dan bintil efektif}

Keberadaan bintil yang efektif dapat menentukan hasil pada tanaman kedelai. Semakin tinggi jumlah dan efektifnya bintil akar mempengaruhi kemampuan tanaman dalam memfiksasi N. Kompos Paitan dan kotoran sapi berpengaruh nyata terhadap jumlah bintil dan jumlah bintil efektif (ditandai dengan warna merah karena mengandung leghemoglobin).

Tabel 9. Berat 100 biji kedelai pada berbagai kombinasi kompos.

\begin{tabular}{lcc}
\hline Perlakuan & $\begin{array}{c}\text { Berat } \\
\text { 100 Biji } \\
(\mathbf{g})\end{array}$ & $\begin{array}{c}\text { Persentase } \\
\text { naik } \\
\mathbf{( \% )}\end{array}$ \\
\hline P0 (Kontrol) & 30,17 & - \\
P1 (100\% & 40,97 & 35,80 \\
Paitan) & & \\
P2 (100\% & 44,16 & 46,37 \\
Kotoran Sapi) & & \\
P3 (75\% Paitan & 40,04 & 32,71 \\
+ 25\% Kotoran & & \\
Sapi) & & \\
P4 (50\% Paitan & 35,12 & 16,40 \\
+ 50\% Kotoran & & \\
Sapi) & & \\
P5 (25\% Paitan & 35,32 & 17,07 \\
+ 75\% Kotoran & & \\
Sapi) & & \\
\hline
\end{tabular}

Perlakuan 100\% kotoran sapi memiliki jumlah bintil akar dan jumlah bintil efektif tertinggi yaitu 115,67 butir/tanaman dan 74,33 butir/tanaman (Tabel 10). Hal ini diduga karena kompos 100\% kotoran sapi memiliki N-total yang rendah dibandingkan pada perlakuan kompos lainnya. Rendahnya kandungan $\mathrm{N}$-total yang diberi akan berdampak meningkatkan jumlah dan efektifnya bintil akar. Hal ini sesuai dengan penelitian Meitasari dan Karuniawan (2017), penambahan nitrogen tidak berpengaruh pembentukan bintil akar, penambahan urea justru menekan jumlah bintil akar yang terbentuk dan aktivitas biologi menjadi tidak efektif (Gambar 2).

\section{Hubungan kualitas kompos terbadap hasil dan bintil} akar tanaman kedelai

Terdapat korelasi positif dan negatif antara parameter kualitas kompos terhadap hasil dan bintil tanaman kedelai (Tabel 11) antara lain: $\mathrm{pH}$ kompos berkorelasi positif dengan hubungan kuat terhadap berat brangkasan $(\mathrm{r}=0,62)$, cukup kuat terhadap berat polong $(\mathrm{r}=0,58)$. 
Jurnal Tanah dan Sumberdaya Lahan Vol 8 No 1: 249-258, 2021

e-ISSN:2549-9793, doi: 10.21776/ub.jts1.2021.008.1.28

Tabel 10. Pengaruh kombinasi kompos terhadap jumlah dan efektifnya bintil akar.

\begin{tabular}{lcc}
\hline Perlakuan & Jumlah Bintil (butir) & $\begin{array}{c}\text { Jumlah Bintil Efektif } \\
\text { (butir) }\end{array}$ \\
\hline P0 (Kontrol) & $42 \mathrm{a}$ & $26 \mathrm{a}$ \\
P1 (100\% Paitan) & $49 \mathrm{a}$ & $38 \mathrm{a}$ \\
P2(100\% Kotoran Sapi) & $115 \mathrm{~b}$ & $74 \mathrm{~b}$ \\
P3 (75\% Paitan + 25\%Kotoran Sapi) & $62 \mathrm{a}$ & $26 \mathrm{a}$ \\
P4 (50\% Paitan + 50\% Kotoran Sapi) & $109 \mathrm{~b}$ & $59 \mathrm{ab}$ \\
P5 (25\% Paitan + 75\% Kotoran Sapi) & $66 \mathrm{a}$ & $34 \mathrm{a}$ \\
\hline Ken
\end{tabular}

Keterangan: Angka yang diikuti huruf sama pada kolom yang sama menunjukkan tidak berbeda nyata menurut uji Duncan taraf 5\%.

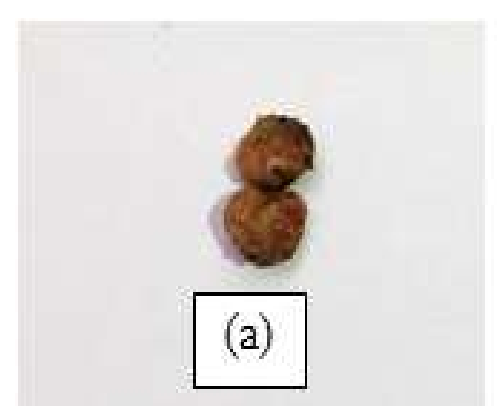

Gambar 2. Bintil akar efektif (a) dan bintil akar tidak efektif (b)
C-organik memiliki hubungan cukup kuat terhadap berat brangkasan $(\mathrm{r}=0,45)$ dan berat polong $(\mathrm{r}=0,49)$. Rasio $\mathrm{C} / \mathrm{N}$ memiliki hubungan kuat terhadap berat polong $(\mathrm{r}=0,63)$. K-Total memiliki hubungan sangat kuat terhadap berat brangkasan $(\mathrm{r}=0,84)$ dan kuat terhadap jumlah bintil efektif $(\mathrm{r}=0,61)$. Pada $\mathrm{N}$ total berkorelasi negatif terhadap berat polong $(\mathrm{r}=-0,47)$, jumlah polong $(\mathrm{r}=-0,37)$ dan jumlah bintil $(\mathrm{r}=-0,02) \cdot \mathrm{pH}$ berhubungan positif dengan hasil dan bintil akar tanaman kedelai karena diikuti dengan meningkatnya berat brangkasan, berat polong, jumlah polong, jumlah serta jumlah efektifnya bintil akar. Aplikasi kompos dapat meningkatkan $\mathrm{pH}$ tanah yang masam menuju netral, yang akan meningkatkan kandungan hara tanah juga sehingga dapat dimanfaatkan tanaman dan mencapai hasil yang meningkat juga. Hal ini sesuai dengan pernyataan Setyorini et al. (2006), pemberian kompos dapat memperbaiki $\mathrm{pH}$ dan meningkatkan hasil tanaman pada lahan pertanian yang memiliki $\mathrm{pH}$ masam. Kandungan C-organik kompos berhubungan positif terhadap hasil dan bintil akar tanaman kedelai karena tingginya C-organik diikuti

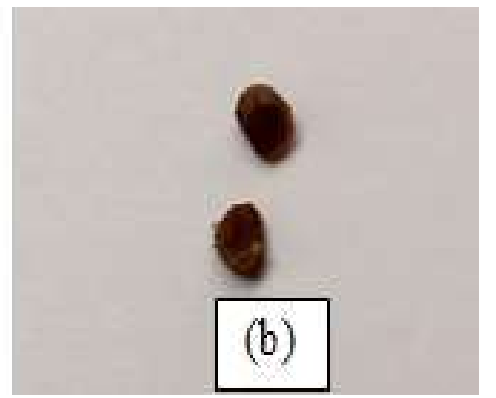

dengan meningkatnya hasil dan bintil akar tanaman kedelai. Dengan meningkatnya Corganik maka bahan organik juga meningkat sehingga dapat meningkatkan hasil dan jumlah bintil tanaman kedelai. Hal ini sesuai dengan pendapat Setyorini et al. (2006), bahwa bahan organik sebagai sumber karbon untuk mikroorganisme tanah yang akan dipergunakan untuk fotosintesis tanaman, dan meningkatkan amonifikasi, nitrifikasi dan fiksasi nitrogen yang membantu proses metabolisme tanaman. Meningkatnya N-total tidak dapat meningkatkan jumlah bintil akar, berat polong dan jumlah polong tanaman kedelai. Rendahnya $\mathrm{N}$ yang diberikan pada tanaman kedelai justru meningkatkan jumlah bintil bintil akar semakin membantu penyediaan hara $\mathrm{N}$ bagi tanaman. Pemberian $\mathrm{N}$ yang tinggi yang diharapkan terinfeksi oleh bakteri membentuk bintil akar kemudian menyediakan hara $\mathrm{N}$ tanaman menjadi terhambat. Rasio $\mathrm{C} / \mathrm{N}$ yang tinggi berpengaruh terhadap berat brangkasan, berat polong dan jumlah polong. Rasio C/N masih masuk kategori kualitas baik (tidak melebihi $\mathrm{C} / \mathrm{N}$ rasio) menurut Kepmentan No.261/KPTS/SR.310/ M/4/2019. 
Jurnal Tanah dan Sumberdaya Lahan Vol 8 No 1: 249-258, 2021

e-ISSN:2549-9793, doi: 10.21776/ub.jts1.2021.008.1.28

Tabel 11. Hubungan kualitas kompos terhadap hasil dan bintil akar kedelai.

\begin{tabular}{|c|c|c|c|c|c|c|c|c|c|c|}
\hline & $\begin{array}{c}\text { Berat } \\
\text { Brangkasan }\end{array}$ & $\begin{array}{c}\text { Berat } \\
\text { Polong }\end{array}$ & $\begin{array}{l}\text { Jumlah } \\
\text { Polong }\end{array}$ & $\begin{array}{c}\text { Bintil yang } \\
\text { Efektif }\end{array}$ & $\begin{array}{c}\text { Jumlah } \\
\text { Bintil }\end{array}$ & $\mathrm{pH}$ & C-organik & N-total & $\begin{array}{c}\text { Rasio } \\
\text { C/N }\end{array}$ & K-total \\
\hline Berat & - & & & & & & & & & \\
\hline \multicolumn{11}{|l|}{ Brangkasan } \\
\hline Berat Polong & $0,37 * *$ & - & & & & & & & & \\
\hline Jumlah Polong & $0,43^{* * *}$ & $0,53 * * *$ & - & & & & & & & \\
\hline Bintil yang & $0,37 * *$ & $0,38^{* *}$ & $0,26^{* *}$ & - & & & & & & \\
\hline \multicolumn{11}{|l|}{ Efektif } \\
\hline Jumlah Bintil & $0,08^{*}$ & $0,07 *$ & $0,07 *$ & $0,12^{*}$ & - & & & & & \\
\hline $\mathrm{pH}$ & $0,62 * * * *$ & $0,58 * * *$ & $0,36 * *$ & $0,38^{* *}$ & $0,04 *$ & - & & & & \\
\hline C-organik & $0,45^{* * *}$ & $0,49 * * *$ & $0,20 *$ & $0,20 *$ & $0,01 *$ & $0,44 * * *$ & & & & \\
\hline N-total & $0,02 *$ & $-0,47$ & $-0,37$ & $0,29 * *$ & $-0,02$ & $-0,07$ & $-0,18$ & - & & \\
\hline Rasio C/N & $0,15^{*}$ & $0,63 * * * *$ & $0,21 * *$ & $-0,05$ & $0,16^{*}$ & $0,11 *$ & $0,55 * * *$ & $-0,70$ & - & \\
\hline K-total & $0,84 * * * * *$ & $0,41^{* *}$ & $0,38 * *$ & $0,61 * * * *$ & $0,06^{*}$ & $0,69 * * * *$ & $0,47 * * *$ & $0,12^{*}$ & $0,04 *$ & - \\
\hline
\end{tabular}

Keterangan: $* * * *=$ korelasi positif hubungan sangat kuat; $* * * *=$ korelasi positif hubungan kuat; $* * *=$ korelasi positif hubungan cukup; $* *=$ korelasi positif hubungan lemah; *= korelasi positif hubungan sangat lemah (Riduwan, 2010) 


\section{Jurnal Tanah dan Sumberdaya Lahan Vol 8 No 1: 249-258, 2021 e-ISSN:2549-9793, doi: 10.21776/ub.jts1.2021.008.1.28}

Menurut Setyorini et al. (2006), bahan organik yang memiliki rasio $\mathrm{C} / \mathrm{N}$ mendekati atau sama dengan rasio $\mathrm{C} / \mathrm{N}$ tanah dapat dimanfaatkan tanaman pada pertumbuhan dan perkembangannya. Meningkatnya K-total berpengaruh positif pada hasil maupun bintil akar tanaman kedelai. Kalium kalium dalam tanah mempengaruhi proses metabolisme, fisiologi, dan nutrisi untuk mencapai tingkat produksi yang tinggi (Andrianto, 2004).

\section{Kesimpulan}

Kompos berkualitas adalah P3 (75\% Paitan + $25 \%$ kotoran sapi), P4 (50\% Paitan $+50 \%$ kotoran sapi) dan P5 (25\% Paitan $+75 \%$ kotoran sapi). Kualitas kompos Paitan dan kotoran sapi berpengaruh nyata terhadap hasil dan bintil akar tanaman kedelai. Perlakuan terbaik adalah P2 (100\% kotoran sapi) yang meningkatkan berat brangkasan tanaman $207,23 \%$, berat polong $25,03 \%$, jumlah bintil akar $182,30 \%$. Terdapat korelasi positif antara parameter kualitas kompos dan hasil dan bintil tanaman kedelai antara lain: $\mathrm{pH}$ kompos berkorelasi positif dengan berat brangkasan $(\mathrm{r}=0,62)$ dan berat polong $(\mathrm{r}=0,58)$. C-organik berkorelasi positif dengan berat brangkasan $(r=0,45)$ dan berat polong $(r=0,49)$. Rasio $\mathrm{C} / \mathrm{N}$ berkorelasi positif terhadap berat polong $(\mathrm{r}=0,63)$. K-total berkorelasi positif dengan berat brangkasan $(\mathrm{r}=0,84)$ dan jumlah bintil efektif $(r=0,61)$.

\section{Daftar Pustaka}

Agustin, S.E., dan Suntari, R. 2018. Pengaruh aplikasi urea dan kompos terhadap sifat kimia tanah serta pertumbuhan jagung (Zea mays L.) pada tanah terdampak erupsi Gunung Kelud. Jurnal Tanah dan Sumberdaya Lahan 5(1): 775 - 783.

Andrianto. 2004. Budidaya dan Analisis Usaha Tani; Kedelai, Kacang Hijau, Kacang Panjang. Cetakan Pertama. Yoyakarta: Absolut.

Bertham, Y.H. 2002. Respon tanaman kedelai (Glycine max L.) terhadap pemupukan fosfor dan kompos jerami pada tanah Ultisol. Jurnal IlmuIlmu Pertanian Indonesia 4(2): 78-83.

Canqui, H.B., Charles, A.S., Charles, S.W., Rhae, A.D., Martha, M., Tim, M.S. dan Richard, B.F. 2013. Soil organic carbon: the value to soil properties. Journal of Soil and Water Conservation 68(5): 129A-134
Idham. 2017. Peningkatan Kualitas Hijauan Melalui Penamabahan Mikroba dari Pupuk Kandang Sapi serta Pengaruhnya terhadap Tanaman Jagung (Zea mays L.). Disertasi. Malang: Universitas Brawijaya.

Keputusan Menteri Pertanian Republik Indonesia. 2019. Persyaratan Teknis Minimal Pupuk Organik, Pupuk Hayati dan Pembenah Tanah. Nomor 261/KPTS/SR.310/M/4/2019.

Martajaya, M., Agustina, M. dan Syekhfani. 2010. Metode budidaya organik tanaman jagung manis di Tlogomas, Malang. Jurnal Pembangunan dan Alam Lestari 1(1): 1-8.

Mayani, N. dan Hapsoh. 2011. Potensi Rhizobium dan pupuk urea untuk meningkatkan produksi kedelai (Glycine max L.) pada lahan bekas sawah. Jurnal Ilmu Pertanian Kultivar 5(2): 21-28.

Meitasari, A.D. dan Karuniawan, P.W. 2017. Inokulasi Rhizobium dan perimbangan nitrogen pada tanaman kedelai (Glycine Max (L) Merill) varietas Wilis. Plantropica: Journal of Agricultural Science 2(1): 55-63

Nuraini, Y. 2012. Efektivitas Berbagai Kompos dalam Stimulasi Mikroorganisme N, P, dan Hormon Pertumbuhan Sebagai Upaya Perbaikan Kesuburan Tanah untuk Peningkatan Produksi Kedelai di Lahan Kering. Disertasi. Universitas Brawijaya.

Riduwan. 2010. Dasar-Dasar Statistika. Bandung: Alfabeta.

Ridwan, A., Nelvia. dan Yosefa, S. 2015. Respon tanaman kedelai (Glycine max(L.) Merrill) sebagai tanaman sela pada kebun kelapa sawit belum menghasilkan (TBM) dengan aplikasi kompos tandan kosong kelapa sawit dan abu boiler. JOM Faperta 2(1): 17-24.

Setyorini, D., Saraswati, R. dan Anwar, E.A. 2006. Kompos, Pupuk Organik Dan Pupuk Hayati. Balai Besar Litbang Sumberdaya Lahan Pertanian. 11-40

Sumarno, dan Manshuri, A. G. 2016. Persyaratan Tumbuh Dan Wilayah Produksi Kedelai di Indonesia. Pusat Penelitian dan Pengembangan Tanaman Pangan. 7-100.

Sumarno, S., Widjianto, H. dan Kusuma, W.R. 2017. Pemberian pupuk alam terhadap serapan nitrogen dan hasil sawi di Alfisol. Jurnal Penelitian Agronomi. 19(2): 33

Suriadikarta, D.A. dan Simanungkalit R.D.M. 2006. Pendahuluan. Pupuk Organik dan Pupuk Hayati. Balai Besar Litbang Sumberdaya Lahan Pertanian. 1-9

Syukur, A. dan Nur, I. 2006. Kajian pengaruh pemberian macam pupuk organik terhadap pertumbuhan dan hasil tanaman jahe. Jurnal Ilmu Tanah dan Lingkungan 6(2): 124-131 
Jurnal Tanah dan Sumberdaya Lahan Vol 8 No 1: 249-258, 2021

e-ISSN:2549-9793, doi: 10.21776/ub.jts1.2021.008.1.28

Utomo, S.B., Nuraini, Y. dan Widianto. 2015. Kajian kemantapan agregat tanah pada pemberian beberapa jenis bahan organik di perkebunan kopi robusta. Jurnal Tanah dan Sumberdaya Lahan 2(1): 111-117.
Wahyuningsih, S. 2019. Buletin Konsumsi Panen. Pusat Data dan Informasi Pertanian. Sekretariat Jendral Kementrian Pertanian. 10(1): 36-46. 